\title{
GENE TRANSFECTION OF BETA 2-ADRENERGIC RECEPTOR INTO THE NORMAL RAT HEART ENHANCES CARDIAC RESPONSE TO BETA-ADRENERGIC AGONIST
}

Youichi Kawahira, MDa

Yoshiki Sawa, MD

Motonobu Nishimura, MD

Satoru Sakakida, MD

Hideki Ueda, MD

Yasufumi Kaneda, $\mathrm{MD}^{\mathrm{b}}$

Hikaru Matsuda, MD
Background: Beta-adrenergic receptor system has a major role in cardiac contraction. If the receptor can be increased by gene transfection by means of intracoronary infusion of beta 2 -adrenergic receptor to the hearts in which the receptor is down-regulated, this maneuver may improve the cardiac function and may be applied as one therapeutic approach during cardiopulmonary bypass or percutaneous cardiopulmonary support. Methods and results: The beta 2-adrenergic receptor complementary DNA was transfected in vivo to the normal rat heart by intracoronary infusion by means of a hemagglutinating virus of Japan liposome method, and the transfected heart was transplanted into the abdomen of another rat. Four days after transfection, the sarcolemma of the cardiomyocytes was well labeled by immunohistochemical labeling. Expression of beta-adrenergic receptor in the heart was approximately 4 times greater than that in control hearts $(134 \pm 42$ vs $33 \pm 4$ fmol/mg protein) according to a ligand binding assay. The cardiac response of the transfected heart to isoproterenol was shown to be enhanced in a Langendorff perfusion system: after isoproterenol, developed pressure and maximal derivative of the left ventricle were greater than in the control heart $(200 \pm 12$ vs $174 \pm 6 \mathrm{~mm} \mathrm{Hg}$ and $4110 \pm 130 \mathrm{vs}$ $3491 \pm 255 \mathrm{~mm} \mathrm{Hg} / \mathrm{sec}$ ), and the minimal derivative of the left ventricle was markedly smaller $(-3040 \pm 267$ vs $-2528 \pm 131 \mathrm{~mm} \mathrm{Hg} / \mathrm{sec})$. Conclusions: These results indicate that expression of beta 2 -adrenergic receptor was approximately 4 times greater than in normal rat hearts by gene transfection using a hemagglutinating virus of Japan liposome method, and the transfected hearts demonstrated marked enhancements in cardiac response to beta-agonist, suggesting that transfer of this gene by intracoronary infusion has potential as a novel approach to enhance cardiac function. (J Thorac Cardiovasc Surg 1999;118:446-51)
The beta-adrenergic receptor (BAR) system plays a major role in cardiac contraction. ${ }^{1}$ Stimulation of the BAR itself leads to activation of adenylyl cyclase and the subsequent production of cyclic adenosine3'5'-monophosphate. ${ }^{1}$ The intracellular calcium level is increased by an opening of the slow calcium channel, and the level is then markedly increased by calcium-

From the First Department of Surgery a and Institute of Molecular

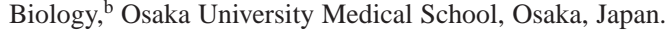

Received for publication Dec 3, 1998; revisions requested Jan 7, 1999; revisions received March 9, 1999; accepted for publication April 29, 1999.

Address for reprints: Yoshiki Sawa, MD, Department of Surgery, Osaka University Medical School, 2-2 Yamadaoka, Suita, Osaka, 565 Japan (E-mail: ykawahir@hsp.ncvc.go.jp).

Copyright (C) 1999 by Mosby, Inc.

$0022-5223 / 99 \$ 8.00+0 \quad \mathbf{1 2 / 1 / 9 9 7 3 0}$ induced release of calcium from the sarcoplasmic reticulum. ${ }^{1}$

Heart failure is a common end result of a variety of cardiac diseases. As this condition develops, the density and affinity of BARs are both known to decrease as a result of an increase in BAR kinase activity, and this is followed by a deterioration in cardiac function. 2,3 Administration of an adrenergic beta-blocking agent or an angiotensin-converting enzyme inhibitor is normally used for such situations. ${ }^{4,5}$ However, the improvement in cardiac function achieved by these therapies is limited.

Gene therapy for human beings has widespread potential applications in clinical medicine. ${ }^{6}$ Various techniques involving gene transfection into the heart have been tested experimentally. ${ }^{7}$ For instance, Milano and associates ${ }^{2}$ created transgenic mice overexpressing beta 2 -adrenergic receptor (B2AR). They reported that 
cardiac function was markedly enhanced, indicating the potential of gene transfer for enhancing cardiac function. However, this transgenic technique causes chronic changes in the essential characteristics of the model, and the technique is not suitable as a therapeutic approach for human beings.

Recently, we reported that a hemagglutinating virus of Japan (HVJ) liposome method could be used as a novel in vivo technique for the transfer of genes into the whole heart with a high efficacy. ${ }^{8}$ If the BAR of the heart could be increased by gene transfection by intracoronary infusion of a plasmid carrying the B2AR complementary DNA, and cardiac function thus enhanced, it might prove possible to use this maneuver as an approach to enhance cardiac function.

In this study, we transfected B2AR cDNA into the normal rat hearts and examined whether such gene was overexpressed in the whole heart and gene transfection was effective in improving the cardiac response to isoproterenol.

\section{Methods}

Animals. Sprague-Dawley rats weighing 200 to $250 \mathrm{~g}$ were used in this study. The rats were treated humanely according to the "Principles of Laboratory Animal Care" formulated by the National Society for Medical Research and the "Guide for the Care and Use of Laboratory Animals" prepared by the Institute of Laboratory Animal Resources and published by the National Institutes of Health (NIH Publication No. 86-23, revised 1985).

DNA construct. Human B2AR cDNA was supplied by Dr R. J. Lefkowitz (Department of Medicine, Duke University, Durham, NC). ${ }^{9}$ It was cloned at the XhoI/HindIII site of pcDNA3.1(-), which has a cytomegalovirus promoter (Invitrogen Corporation, San Diego, Calif). As a control, a DNA construct of pcDNA3.1(-) that does not include B2AR cDNA was used.

Transfection using an HVJ-liposome method. The preparation of the HVJ liposome has been described elsewhere. ${ }^{10,11}$ In brief, $10 \mathrm{mg}$ of lipid mixture (phosphatidylserine, phosphatidylcholine, and cholesterol) was deposited on the wall of a flask by removing tetrahydrofuran in a rotary evaporator. The dried lipid was hydrated in $200 \mu \mathrm{L}$ of balanced salt solution $(\mathrm{NaCl}, 137.0 \mathrm{mmol} / \mathrm{L} ; \mathrm{KCl}, 5.4 \mathrm{mmol} / \mathrm{L}$; Tris-HCl, $10.0 \mathrm{mmol} / \mathrm{L}$; $\mathrm{pH}$ 7.6) containing a DNA $(50 \mu \mathrm{g})-$ HMG1 (high mobility group 1 nuclear protein, $64 \mu \mathrm{g}$ ) complex. A liposome-DNA-HMG1 complex suspension was prepared by spinning in a vortex, sonicating, and shaking to form liposomes. The liposome suspension was incubated with 30,000 hemagglutinating units of $\mathrm{HVJ}$ (inactivated by ultraviolet irradiation), first at $4{ }^{\circ} \mathrm{C}$ and then at $37^{\circ} \mathrm{C}$. Finally, $4 \mathrm{~mL}$ of the sucrose gradient layer containing the HVJ-liposomeDNA complex was collected for use.

Transfection of the B2AR. ${ }^{8}$ The Sprague-Dawley rat was anesthetized with sodium pentobarbital $(0.5 \mathrm{~mL} / \mathrm{kg}$, intraperi- toneally). The heart was arrested by infusion of cardioplegic solution, which contained the following (in millimoles per liter): $\mathrm{NaCl}, 110.0 ; \mathrm{NaHCO}_{3}, 10.0 ; \mathrm{KCl}, 16.0 ; \mathrm{MgCl}_{2}, 16.0$; $\mathrm{CaCl}_{2}, 1.2$; and lidocaine, 1.0. Both caval veins were ligated and transected. After branches of the aortic arch had also been ligated, the descending aorta was transected. Then the pulmonary arteries and veins were ligated and the heart was removed. Approximately $0.7 \mathrm{~mL}$ of the HVJ-liposome-DNA complex (including $50 \mu \mathrm{g}$ of B2AR cDNA) was infused via the aorta into the resected heart ("coronary perfusion"). The heart was incubated on ice for 10 minutes to give sufficient time for gene transfection into the cardiomyocytes. ${ }^{8}$ Then transfected heart was transplanted into the abdomen of another Sprague-Dawley rat of the same strain, with the recipient rat under sodium pentobarbital anesthesia $(0.5 \mathrm{~mL} / \mathrm{kg}$, intraperitoneally). The transplantation was performed by anastomosing the descending aorta to the abdominal aorta and the pulmonary artery to the inferior caval vein in an endto-side fashion (a modification of the Ono and Lindsey technique $^{12}$ ). The ischemic time was $40 \pm 3$ minutes. The transplanted hearts were resuscitated to spontaneous, continuous beating after restoration of coronary blood flow. The hearts transfected with the plasmid including the construct of B2AR DNA are referred to as the transfected group $(n=25)$ and the hearts transfected with the plasmid not including B2AR DNA are designated the control group $(n=25)$. Four days after the transfection, 5 hearts in each group were used for immunohistochemical labeling and 10 hearts for the ligand binding assay; the cardiac function of the remaining 10 hearts in each group was analyzed by means of a Langendorff system.

Immunohistochemical labeling. Four days after transfection, 5 hearts from each group were removed and quickly frozen in embedding medium (optimum cutting temperature compound; Miles Inc, Diagnostics Division, Elkhart, Ind) using liquid nitrogen. Then, the frozen sections were cut at 7 $\mu \mathrm{m}$ and rinsed 3 times for 3 minutes each time in phosphatebuffered saline solution (PBS) and for 3 minutes in PBS with 0.05\% Triton X-100 (Triton-PBS; Union Carbide Corp, Danbury, Conn). They were then blocked with serum diluent ( $10 \%$ goat serum in PBS with $0.1 \%$ bovine serum albumin and $0.1 \%$ sodium azide). Next, the sections were rinsed for 15 minutes in Triton-PBS before overnight incubation at $4{ }^{\circ} \mathrm{C}$ with a primary rabbit antihuman BAR antiserum ${ }^{13}(1: 3000$ dilution in serum diluent). They were then washed 4 times for 10 minutes each time in Triton-PBS at room temperature and incubated for 1 hour in fluorescein isothiocyanate-conjugated goat antirabbit immunoglobulin G (1:500 dilution in serum diluent). After five 3-minute rinses in PBS, the sections were mounted with sodium iodide $(25 \mathrm{mg} / \mathrm{L})$ in $1: 1$ glycerol solution.

Ligand binding assay. Four days after transfection, hearts were removed from the recipient rats (10 from each group) and quickly frozen with liquid nitrogen. Then, to isolate the sarcolemma of the myocytes, the ventricles of the transfected hearts were placed in ice-cold lysis homogenization buffer (sucrose $[0.25 \mathrm{~mol} / \mathrm{L}]$ containing Tris- $\mathrm{HCl}[5 \mathrm{mmol} / \mathrm{L}]$ and $\mathrm{MgCl}_{2}$ [1 mmol/L], $\mathrm{pH}$ 7.4) and homogenized using a 

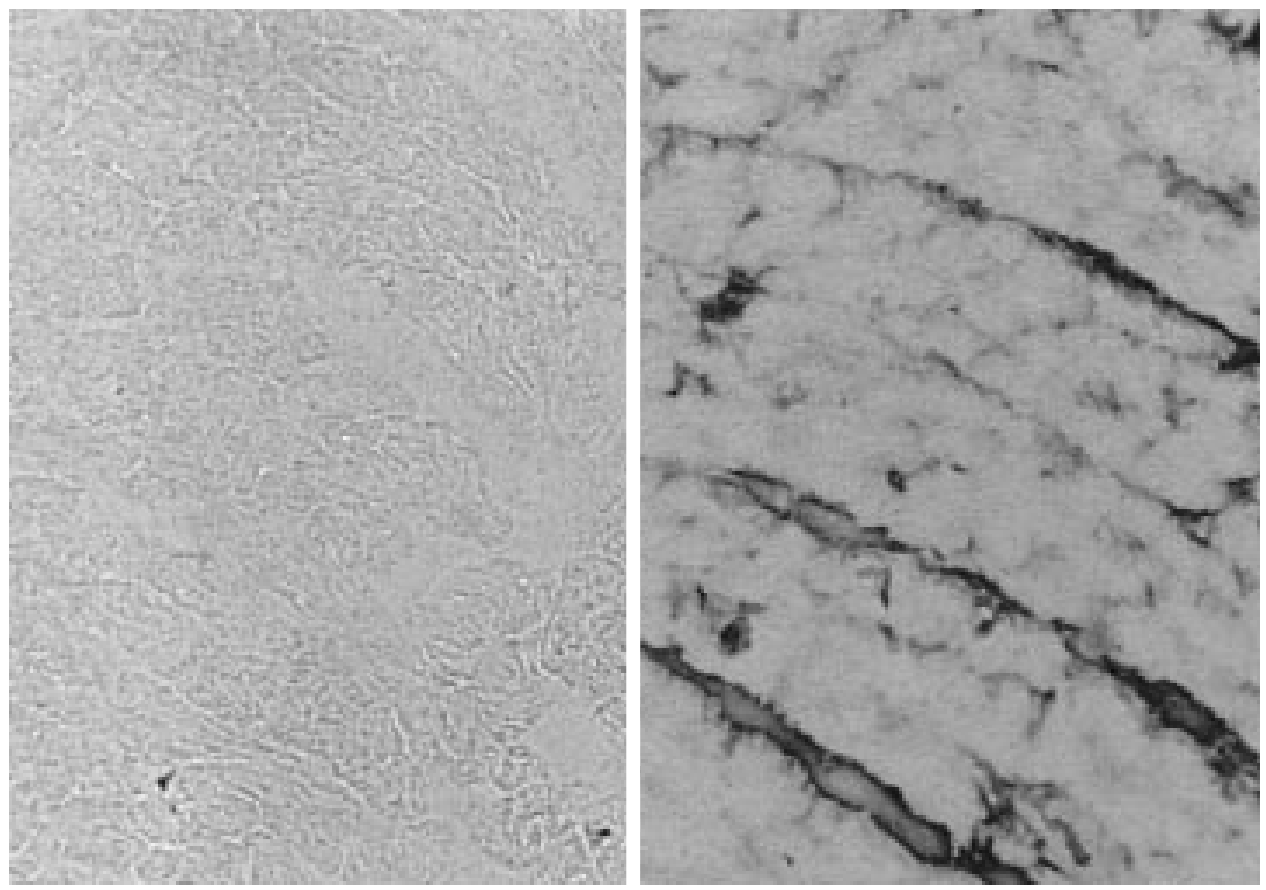

Fig 1. Immunohistochemical labeling for human B2AR showing extensive overexpression of B2AR in the sarcolemma of the cardiomyocytes of the transfected group.

Polytron homogenizer (Nihon Seimitsu-Kogyo Co, Japan) 3 times for 15 seconds each time at a power setting of 6 . After an initial $800 \mathrm{~g}$ centrifugation for 10 minutes, the supernatant was filtered through a single layer of cheesecloth and centrifuged at $30,000 \mathrm{~g}$ for 30 minutes. The pellets were suspended in a $5 \mathrm{mmol} / \mathrm{L}$ concentration of Tris- $\mathrm{HCl}$ buffer (Tris$\mathrm{HCl}, 50 \mathrm{mmol} / \mathrm{L} ; \mathrm{MgCl}_{2}, 10 \mathrm{mmol} / \mathrm{L} ; \mathrm{pH}$ 7.4) and recentrifuged at $30,000 \mathrm{~g}$ for 30 minutes. Some of the resultant pellets were resuspended in another buffer (Tris- $\mathrm{HCl}, 10$ $\mathrm{mmol} / \mathrm{L}$; ethyleneglycoltetraacetic acid, $1 \mathrm{mmol} / \mathrm{L} ; \mathrm{pH} 7.4)$. The assay buffer was Tris- $\mathrm{HCl}(20 \mathrm{mmol} / \mathrm{L}), \mathrm{NaCl}(150$ $\mathrm{mmol} / \mathrm{L})$, and ascorbic acid ( $1 \mathrm{mmol} / \mathrm{L}), \mathrm{pH} 7.4$, at room temperature (Tris- $\mathrm{NaCl}$ buffer). For measurement of BAR density, duplicate tubes were prepared containing 6 increasing concentrations of $\left[{ }^{125} \mathrm{I}\right]$-cyanopindolol (from $5.0 \times 10^{-12}$ $\mathrm{mol} / \mathrm{L}$ to $1.5 \times 10^{-10} \mathrm{~mol} / \mathrm{L}$ ) with or without $10^{-6} \mathrm{~mol} / \mathrm{L}(-)$ propranolol, giving a total volume of $150 \mu \mathrm{L}$. The assay was begun by adding $300 \mu \mathrm{L}$ of membrane preparation, and incubation then proceeded for 60 minutes at $37^{\circ} \mathrm{C}$. This method allowed for complete equilibration of the receptor with the radioligand. Bound and free ligands were separated by the addition of $5 \mathrm{~mL}$ Tris- $\mathrm{HCl}$ buffer (at room temperature), rapid filtration through Whatman GF/F filters (Whatman, Inc, Clifton, NJ), and immediate washing with an additional 15 $\mathrm{mL}$ of the same buffer. Filters were counted at $70 \%$ efficiency in a gamma counter (model MINAXI-gamma, Pachard Ins Co, Meriden, Conn). The dose of membrane protein was determined according to Bradford's method. ${ }^{14}$

Measurement of cardiac function in the transfected rat heart. Cardiac function was measured by a person who did not know whether the heart was in the transfected group or in the control group. Four days after transfection, recipient rats (10 from each group) were anesthetized with sodium pentobarbital $(0.5 \mathrm{~mL} / \mathrm{kg}$, intraperitoneally) and killed after an intravenous infusion of heparin $(1000 \mathrm{U} / \mathrm{kg})$. The hearts were removed and immersed in cold $\left(4^{\circ} \mathrm{C}\right)$ buffer. Each heart was then mounted on the aortic cannula $(2.5 \mathrm{~mm}$ outside diameter) of the perfusion apparatus. The coronary arteries were perfused according to the Langendorff technique at a perfusion pressure of $100 \mathrm{~cm} \mathrm{H}_{2} \mathrm{O}$ for both groups. The KrebsHenseleit solution contained the following (in millimoles per liter): $\mathrm{NaCl}, 118.5 ; \mathrm{NaHCO}_{3}, 25.0 ; \mathrm{KCl}, 4.8 ; \mathrm{MgSO}_{4}, 1.2$; $\mathrm{CaCl}_{2}, 1.25$; and glucose, 11.0. The buffer was filtered $(5-\mu \mathrm{m}$ pore size) before use and was continuously gassed with $95 \%$ oxygen and $5 \%$ carbon dioxide to obtain $\mathrm{pH} 7.4$ at $37^{\circ} \mathrm{C}$. Each heart was housed in a controlled heart chamber maintained at $37^{\circ} \mathrm{C}$. During a 10 -minute washout period after cannulation, an intraventricular balloon ( $8 \mathrm{~mm}$ in diameter) was inserted into the left ventricle through the mitral valve. The balloon was filled with fluid and attached to a pressure transducer through a fluid-filled tube. The volume of the balloon was adjusted by means of a watertight microsyringe attached to a side arm of the transducer. Before infusion of isoproterenol, heart rate, developed pressure, and maximal and minimal derivatives of the left ventricle ( $\max$ and $\min \mathrm{dp} / \mathrm{dt}$ ) were measured at a constant left ventricular end-diastolic pressure (set at $10 \mathrm{~cm} \mathrm{H}_{2} \mathrm{O}$ for both groups). About 45 to 60 seconds after each infusion of isoproterenol $\left(4 \times 10^{-12} \mathrm{~g}, 2.5\right.$ $\times 10^{-10} \mathrm{~g}, 4 \times 10^{-8} \mathrm{~g}, 2.5 \times 10^{-6} \mathrm{~g}$, or $1 \times 10^{-5} \mathrm{~g}$ ), maximum values of heart rate, developed pressure, and max and min 


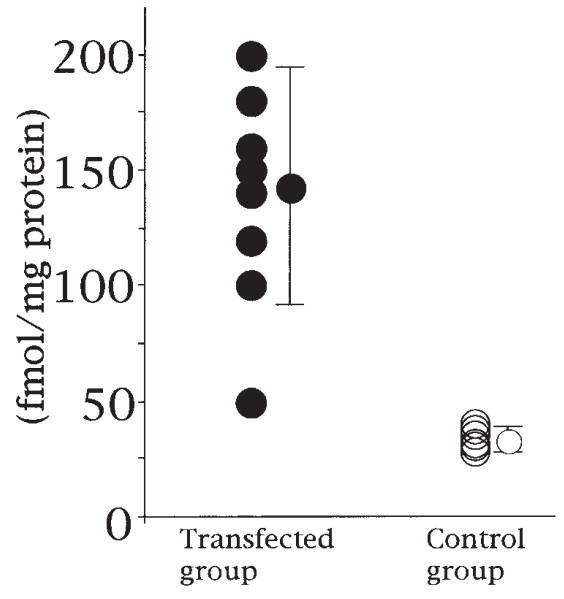

Fig 2. Ligand binding assay for measurement of BAR density showing significant increase of the density in the hearts of the transfected group $(P=.0001)$.

$\mathrm{dp} / \mathrm{dt}$ were also measured. The various concentrations of isoproterenol were applied in an ascending order.

Statistical analysis. All values are expressed as mean \pm standard deviation. Differences in receptor density were assessed by means of a Mann-Whitney test. Differences in cardiac function data were assessed with the use of a 2-way repeated-measures analysis of variance. If a significant $\mathrm{F}$ ratio was obtained, further analysis was carried out with Duncan's post hoc test. All analysis was performed with SPSS statistical software (SPSS, Inc, Chicago, Ill). Differences between groups were considered significant at the $P<$ .05 level.

\section{Results}

Mortality after gene transfection. There were no technical failures and no operative deaths in the 25 consecutive trials in each group.

Immunohistochemical labeling. No substantial changes in histologic appearance occurred. Extensive overexpression of B2AR in the sarcolemma of the cardiomyocytes, in which B2AR are located, was well labeled in the transfected group; by contrast, no part of the heart was labeled in the control group (Fig 1). The cytoplasm of the cardiomyocytes was not labeled in either group.

Ligand binding assay. The values for BAR density in the hearts of the transfected and control groups were $134 \pm 42 \mathrm{fmol} / \mathrm{mg}$ protein and $33 \pm 4 \mathrm{fmol} / \mathrm{mg}$ protein, respectively $(P=.0001)$ (Fig 2$)$.

Evaluation of cardiac function. The heart rates obtained under basal conditions in the transfected and control groups were $373 \pm 60$ beats/min and $347 \pm 31$ beats/min, respectively. In the transfected group, heart rate was maximally elevated to $418 \pm 36$ beats $/ \mathrm{min}$ after infusion of $2.5 \times 10^{-6} \mathrm{~g}$ of isoproterenol, and in
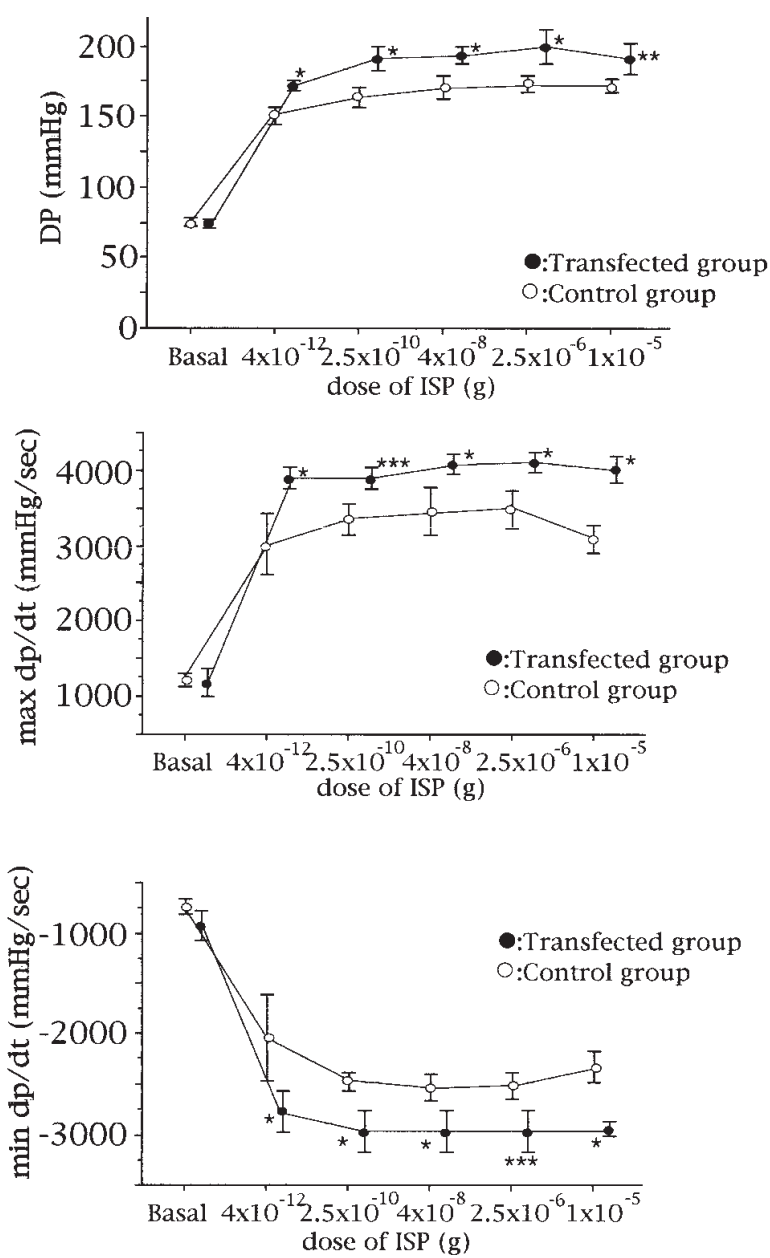

Fig 3. Cardiac response to isoproterenol (ISP). Top and middle, Changes of developed pressure $(D P)$ and maximal derivative of the left ventricle ( $\max d p / d t$ ) showing the significant increase in these values in the transfected group after each infusion of isoproterenol of $4.0 \times 10^{-12} \mathrm{~g}$ or more than those in the control group $\left({ }^{*} P=.0001,{ }^{* *} P=.0008,{ }^{* * *} P=.0007\right)$. Bottom, Changes of minimal derivative of the left ventricle ( $\min d p / d t$ ) showing the significant decrease of the values in the transfected group compared with that in the control group after each infusion of isoproterenol of $4.0 \times 10^{-12} \mathrm{~g}$ or more $\left({ }^{*} P=.0001,{ }^{* * *} P=.0007\right)$.

the control group it was maximally elevated to $438 \pm$ 27 beats/min after infusion of $2.5 \times 10^{-6} \mathrm{~g}$ of isoproterenol. Heart rate before and after infusion of each dose of isoproterenol did not differ between the transfected and control groups.

Developed pressure under basal conditions was $74 \pm$ $3 \mathrm{~mm} \mathrm{Hg}$ in the transfected group and $76 \pm 3 \mathrm{~mm} \mathrm{Hg}$ in the control group. In the transfected group, developed pressure was maximally elevated to $200 \pm 12 \mathrm{~mm}$ $\mathrm{Hg}$ after infusion of $2.5 \times 10^{-6} \mathrm{~g}$ of isoproterenol, 
whereas in the control group it was maximally elevated to $174 \pm 6 \mathrm{~mm} \mathrm{Hg}$ after infusion of $2.5 \times 10^{-6} \mathrm{~g}$. Under basal conditions, developed pressure did not differ between the 2 groups, but the developed pressure in the transfected group was significantly higher than that in the control group after each infusion of isoproterenol of $4.0 \times 10^{-12} \mathrm{~g}$ or more $(P=.0001$ or .0008$)$ (Fig 3; top).

Max dp/dt under basal conditions was $1184 \pm 187$ $\mathrm{mm} \mathrm{Hg} / \mathrm{sec}$ in the transfected group and $1230 \pm 87 \mathrm{~mm}$ $\mathrm{Hg} / \mathrm{sec}$ in the control group. Max dp/dt was maximally elevated to $4110 \pm 130 \mathrm{~mm} \mathrm{Hg} / \mathrm{sec}$ after infusion of 4 $\times 10^{-8} \mathrm{~g}$ of isoproterenol in the transfected group and to $3491 \pm 255 \mathrm{~mm} \mathrm{Hg} / \mathrm{sec}$ after infusion of $2.5 \times 10^{-6} \mathrm{~g}$ of isoproterenol in the control group. Under basal conditions, max dp/dt did not differ between the 2 groups; however, max dp/dt was significantly greater in the transfected group than in the control group after each infusion of isoproterenol of $4.0 \times 10^{-12} \mathrm{~g}$ or more $(P=$ .0001 or .007) (Fig 3; middle).

Min dp/dt under basal conditions was $-743 \pm 121$ $\mathrm{mm} \mathrm{Hg} / \mathrm{sec}$ in the transfected group and $-741 \pm 75 \mathrm{~mm}$ $\mathrm{Hg} / \mathrm{sec}$ in the control group. Min dp/dt in the transfected group decreased to a minimum of $-3040 \pm 267 \mathrm{~mm}$ $\mathrm{Hg} / \mathrm{sec}$ after $4 \times 10^{-8} \mathrm{~g}$ of isoproterenol and in the control group to $-2528 \pm 131 \mathrm{~mm} \mathrm{Hg} / \mathrm{sec}$ after $4 \times 10^{-8} \mathrm{~g}$ of isoproterenol. Min dp/dt did not differ between the 2 groups; however, min dp/dt was significantly lower in the transfected group than in the control group after each infusion of isoproterenol of $4.0 \times 10^{-12} \mathrm{~g}$ or more $(P=.001$ or .0001) (Fig 3; bottom).

\section{Discussion}

In this study, we have shown by gene transfection using an HVJ-liposome method that the B2AR can be successfully overexpressed in the normal rat heart and that, as a result, an apparent enhancement in the cardiac functional response was demonstrated in these transfected rats.

Gene transfection into the heart has been proposed as a new method of treatment for the failing heart or myocardial damage. A number of trials have been reported using such methods as intravenous infection, ${ }^{15}$ direct infection, ${ }^{16}$ or intracoronary infusion of a naked plasmid. ${ }^{17}$ However, we have yet to see established a method of gene transfection for the entire heart that is satisfactory in the sense that it leads to overexpression of a protein and modification of myocardial characteristics with high efficiency. Recently, Sawa and associates $^{8}$ reported an efficient in vivo gene transfection method to the entire rat heart using the intracoronary infusion of HVJ liposomes. Fluorescein isothiocyanate and beta-galactosidase can be overexpressed in the whole rat heart. Suzuki and coworkers ${ }^{18}$ also reported that ischemia-reperfusion injury was attenuated when heat shock protein 70 was overexpressed by this method. In this method, 10 minutes of incubation $\left(0^{\circ} \mathrm{C}\right)$ is required to transform the vector including cDNA, and more than 4 days is also required to express the protein induced by the transfected cDNA. ${ }^{10,11}$

The BAR system has a major role in cardiac contraction. ${ }^{3}$ BAR itself mediates effects through activation of adenylyl cyclase to produce cyclic adenosine-3'5'monophosphate, which increases intracellular concentration of calcium and causes excitation-contraction coupling. ${ }^{3}$ In the failing heart, density and affinity of the receptor decrease and activity of BAR kinase increases. These changes in the BAR system exacerbate cardiac dysfunction. ${ }^{1}$

Milano and associates ${ }^{2}$ created transgenic mice overexpressing human B2AR and found that they displayed marked improvements in left ventricular function. Although the transgenic technique is a novel and useful method for the evaluation of the effects of the superoverexpression of specific genes, it has no value as a therapeutic approach for human beings with cardiac disease. An alternative therapeutic approach might be an effective in vivo gene transfer method, one requirement being that the method chosen must be safe to use in a patient with a failing heart. Since the HVJ-liposome method used in this study requires 10 minutes of incubation on ice for the HVJ-liposome-DNA complex to adhere to the cardiomyocytes so that the DNA can be transfected into the myocytes, ${ }^{10,11}$ approximately 10 minutes of cardiac arrest is needed to apply this technique to clinical settings. In fact, in vivo transfection of the B2AR gene into the heart by intracoronary perfusion should be possible in human beings as a surgical technique during cardiac arrest under cardiopulmonary bypass or as a catheter intervention technique during cardiac arrest under a percutaneous cardiopulmonary support system. ${ }^{8}$

The ability of our maneuver to enhance cardiac function could be questioned because there was no difference in cardiac function under basal conditions between the transfected and control groups in this study. However, we have an optimistic view of these results: the intracellular calcium level, which is very important in excitation-contraction coupling in cardiomyocytes, is determined by the extracellular calcium level and the opening of the slow calcium channel. As there was no beta-adrenergic agonist to induce opening of the slow calcium channel under basal conditions in our Langendorff perfusion system, it is not surprising that cardiac function did not differ between 
the transfected and control groups in the absence of isoproterenol. The lack of increase in baseline condition in the transfected group may also be related to desensitization or internalization of the receptor. Although further study in larger animals will be needed to elucidate this point, we would anticipate differences in cardiac function under basal conditions in the intact animal.

In summary, B2AR was able to be overexpressed approximately 4 times in the whole rat hearts by gene transfection using an HVJ-liposome method. The transfected hearts demonstrated marked enhancements in cardiac response after infusion of isoproterenol, suggesting that this procedure may have a place in the treatment of the failing heart and, in particular, may provide us with a novel cardiac surgical procedure.

We are grateful to Dr Robert J. Lefkowitz, James B. Duke Professor of Medicine, Duke University Medical Center, Durham, North Carolina, for his giving us the cDNA of human beta 2 adrenergic receptor and for technical collaboration and thoughtful advice.

\section{REFERENCES}

1. Jones CR, Molenaar P, Summers RJ. New views of human cardiac beta-adrenoceptors. J Mol Cell Cardiol 1989;21:519-35.

2. Milano CA, Allen LF, Rockman HA, Dolber PC, McMinn TR, Chien KR, et al. Enhanced myocardial function in transgenic mice overexpressing the beta-adrenergic receptor. Science 1994; 264:582-6.

3. Koch WJ, Rockman HA, Samama P, Hamilton RA, Bond RA, Milano CA, et al. Cardiac function in mice overexpressing the beta-adrenergic receptor kinase or a BARK inhibitor. Science 1995;268:1350-3.

4. Waagstein F. Adrenergic beta-blocking agents in congestive heart failure due to idiopathic dilated cardiomyopathy. Eur Heart J 1995;16:128-32.

5. Cleland JG. The clinical course of heart failure and its modification by ACE inhibitors: insights from recent clinical trials. Eur Heart J 1994;15:125-30.
6. Wheeler VS. Gene therapy: current strategies and future applications. Oncol Nurs Forum 1995;22(2 Suppl):20-6.

7. Herttuala S. Gene therapy for cardiovascular diseases. Ann Med 1996;28:89-93.

8. Sawa Y, Kadoba K, Suzuki K, Bai HZ, Kaneda Y, Shirakura R, et al. Efficient gene transfer method into the whole heart through the coronary artery with hemagglutinating virus of Japan liposome. J Thorac Cardiovasc Surg 1997;113:512-9.

9. Kobilka BK, Dixon RA, Frielle T, Dohlman HG, Bolanowski MA, Sigal IS, et al. cDNA for the human beta2 adrenergic receptor: a protein with multiple membrane-spanning domains and encoded by a gene whose chromosomal location is shared with that of the receptor for platelet-derived growth factor. Proc Natl Acad Sci U S A 1987;84:46-50.

10. Kaneda Y, Iwai K, Uchida T. Increased expression of DNA cointroduced with nuclear protein in adult rat liver. Science 1989; 243:375-8.

11. Kaneda Y. Virus (Sendai virus envelopes)-mediated gene transfer. In: Celis JE, editor. Cell biology, a laboratory handbook. Vol III. New York: Academic Press; 1994. p. 50-7.

12. Ono K, Lindsey E. Improved technique of heart transplantation in rats. J Thorac Cardiovasc Surg 1969;57:225-9.

13. von Zastrow M, Kobilka BK. Ligand-regulated internalization and recycling of human beta2-adrenergic receptors between the plasma membrane and endosomes containing transferrin receptors. J Biol Chem 1992;88:3530-8.

14. Bradford MM. A rapid and sensitive method for the quantitation of microgram quantities of protein utilizing the principle of protein-dye binding. Anal Biochem 1976;72:248-54.

15. Statford-Perricaudet LD, Makeh I, Perricaude M, Briand P. Widespread long-term gene transfer to mouse skeletal muscles and hearts. J Clin Invest 1992;90:626-30.

16. Lin H, Parmacek MS, Morle G, Bolling S, Leiden JM. Expression of recombinant genes in myocardium in vivo after direct infection of DNA. Circulation 1990;82:2217-21.

17. Ardehali A, Fyfe A, Laks H, Drinkwater DC, Qiao JH, Lusis AJ. Cardiac and pulmonary replacement: direct gene transfer into donor hearts at the time of harvest. J Thorac Cardiovasc Surg 1995; 109:716-20.

18. Suzuki K, Sawa Y, Kaneda Y, Ichikawa H, Shirakura R, Matsuda $H$. In vivo gene transfection with heat shock protein 70 enhances myocardial tolerance to ischemia-reperfusion injury in rat. J Clin Invest 1997;99:1645-50. 